\title{
Enhancement of ovarian follicle development in heifers by treatment with recombinant bovine somatotrophin: a dose-response study
}

\author{
J. G. Gong ${ }^{1,2 *}$, G. Baxter ${ }^{1}$, T. A. Bramley ${ }^{2}$ and R. Webb $^{1 \dagger}$ \\ ${ }^{1}$ Roslin Institute (Edinburgh), Roslin, Midlothian EH25 9PS, UK; and ${ }^{2}$ Department of Obstetrics and \\ Gynaecology, University of Edinburgh, Centre for Reproductive Biology, 37 Chalmers Street, \\ Edinburgh EH3 $9 E W$, UK
}

\begin{abstract}
Treatment with recombinant bovine somatotrophin (bST) can enhance the development of ovarian antral follicles in cattle. The underlying mechanism was examined further by performing a dose-response study to investigate the effects of bST on peripheral concentrations of somatotrophin, insulin-like growth factor I (IGF-I), insulin, FSH and LH, and ovarian follicle development. Twenty mature heifers were randomly divided into five groups and injected s.c. at $6 \mathrm{~h}$ intervals for 7 days with $25 \%$ of one of the following daily doses of bST: $0,3.13,6.25,12.5$ or $25.0 \mathrm{mg}$. Ovarian follicular dynamics were monitored by real-time ultrasonography. Blood samples were collected daily during the experiment, and every $15 \mathrm{~min}$ for $8 \mathrm{~h}$ on days $\mathrm{I}$ and 5 of bST treatment. Treatment with bST increased $(P<0.01)$ peripheral concentrations of somatotrophin in a dose-dependent manner. Serum concentrations of both IGF-I and insulin were significantly $(P<0.01)$ increased in all heifers given 12.5 or $25.0 \mathrm{mg}$ bST per day. Peripheral concentrations of IGF-I and insulin in all animals in the group given $3.13 \mathrm{mg}$ bST and two heifers in the group given $6.25 \mathrm{mg}$ bST were not different from those in the control group, while concentrations in the other two heifers given $6.25 \mathrm{mg}$ bST were significantly $(P<0.01)$ higher. The number of ovarian follicles $<5 \mathrm{~mm}$ in diameter was increased $(P<0.05)$ in response to $\mathrm{bST}$, but only in heifers $(n=10)$ with significantly increased serum concentrations of IGF-I and insulin. There were no effects of treatment on peripheral concentrations of FSH, LH and progesterone, and on the numbers of follicles $>5 \mathrm{~mm}$ in diameter. In conclusion, this study has demonstrated in vivo that the effect of treatment with bST on ovarian follicle development appears to be mediated through an increase in circulating IGF-I or insulin concentrations, rather than via an alteration in the secretion of pituitary gonadotrophins or a direct effect of bST on ovarian follicles.
\end{abstract}

\section{Introduction}

Several recent studies have demonstrated that treatment with recombinant bovine somatotrophin (bST) can enhance the development of ovarian antral follicles in cattle (Gong et al., 1991, 1993a; De La Sota et al., 1993; Lucy et al., 1993a; Herrler et al., 1994; see Webb et al., 1994; Pavlok et al., 1996). Although bST treatment was found to increase significantly the peripheral concentrations of somatotrophin, insulin-like growth factor I (IGF-I) and insulin (Gallo and Block, 1991; Gong et al., 1991, 1993a; De La Sota et al., 1993; Herrler et al., 1994; Pavlok et al., 1996), the mechanism underlying this effect of bST is still not fully understood. Both IGF-I and insulin, given alone or in combination with gonadotrophins, have been shown to have a profound effect on the proliferation and steroidogenesis of

\section{*Correspondence.}

"Present address: Department of Agriculture and Horticulture, University of Nottingham, Sutton Bonington Campus, Loughborough, Leicestershire LE12 5RD, UK.

Received 23 October 1996. cultured bovine granulosa cells (Savion et al., 1981; Saumande, 1991; Gong et al, 1993b, 1994; Spicer et al., 1993; Gutierrez et al., 1995; see Spicer and Echternkamp, 1995). However, whether somatotrophin has a direct effect on bovine ovarian follicles remains equivocal. Although an effect of bST on the proliferation and steroidogenesis of cultured bovine granulosa cells has been observed in some studies (Langhout et al., 1991; Gong et al., 1993b, 1994; Sirotkin and Makarevic, 1996), the expression of a bovine somatotrophin receptor could not be detected in bovine antral follicles (Lucy et al., 1993b). Furthermore, although no apparent long-term alterations in circulating concentrations of FSH and LH were observed in bST-treated heifers (Gong et al., 1991), whether there is an acute effect of bST treatment on the secretion of gonadotrophins, like that reported previously in lactating dairy cows (Schemm et al., 1990; Gallo and Block, 1991), has yet to be clarified.

The mechanism underlying the effect of bST on ovarian follicle development was examined further in this study. The objectives were: (1) to investigate whether a more physiological regimen of bST treatment has a similar effect on follicle 
development to that observed in our previous studies (Gong et al., 1991, 1993a) that used pharmacological doses (either $25 \mathrm{mg}$ daily or a single dose of $320 \mathrm{mg}$ in a sustained release formulation); (2) to assess the relative importance of somatotrophin, IGF-I and insulin by giving different doses of bST to obtain a differential response in these three hormones and ovarian follicular populations; and (3) to examine the acute effects of bST treatment on the secretion of $\mathrm{FSH}$ and $\mathrm{LH}$ in heifers.

\section{Materials and Methods}

\section{Experimental animals}

The animals used for this study were Hereford $\times$ Friesian beef heifers, approximately 2.5 years of age. The heifers were kept indoors under natural photoperiod in a large court, fed hay and concentrates twice a day with free access to water, as per normal practice in our Institute Farms. Before the experiment, animals were given halter training and it was confirmed that they displayed oestrous cycles. Oestrus was monitored by behavioural observations four times a day, aided by a Kamar heatmount detector (Kamar Inc., Steamboat Springs, CO).

All the experimental procedures were carried out in accordance with our Institute's Code of Practice for the Use of Experimental Animals in Research, under the UK Home Office Animals (Scientific Procedures) Act of 1986.

\section{Experimental procedures}

Oestrous cycles of 20 heifers were synchronized by two i.m. injections, given 11 days apart, of $500 \mu \mathrm{g}$ synthetic prostaglandin $\mathrm{F}_{2 \alpha}$ (Estrumate, Coopers Animal Health Ltd, Crewe). Animals were assigned to five treatment groups in a randomized block design. Starting from day 7 of the synchronized oestrous cycle (day of oestrus taken as day 0 ), animals in each group were injected s.c. four times a day (at 06:00, 12:00, 18:00 and $24: 00 \mathrm{~h}$ ) for 7 days, with $25 \%$ of one of the following daily doses of bST: $0,3.13,6.25,12.5$ or $25.0 \mathrm{mg}$. Recombinant bovine somatotrophin (somidobove; Elanco Animal Health, Basingstoke) was diluted to $1 \mathrm{mg} \mathrm{ml}{ }^{-1}$ in a vehicle containing $0.9 \%(\mathrm{w} / \mathrm{v}) \mathrm{NaCl}, 0.025 \mathrm{~mol} \mathrm{NaHCO}_{3} \mathrm{I}^{-1}$ and $0.025 \mathrm{~mol} \mathrm{Na}_{2} \mathrm{CO}_{3} \mathrm{l}^{-1}$. The duration of treatment ( 7 days) was based on observations from our previous study (Gong et al., 1993a) that bST increases peripheral concentrations of somatotrophin, IGF-I and insulin and ovarian follicle populations within 2-3 days of the start of treatment. Serum samples were collected from all animals daily (at 12:00 h) from days 5 to 16 of the synchronized oestrous cycle. Serial plasma samples (every $15 \mathrm{~min}$ from 05:30 to $13: 30 \mathrm{~h}$ ) were collected on days 1 and 5 of bST treatment. Samples were measured for progesterone, FSH, LH, somatotrophin, IGF-I and insulin concentrations by specific radioimmunoassays. The ovaries of all heifers were scanned daily using real-time ultrasonography throughout the experimental period to monitor the dynamics of follicle growth and development, as described by Gong et al. (1993a).

\section{Hormone assays}

Progesterone. Serum progesterone concentrations were measured using a radioimmunoassay described by Corrie et al. (1981) and modified in our laboratory for a direct-assay procedure (Law et al., 1992). The minimum detectable concentration was $0.11 \mathrm{ng} \mathrm{ml}^{-1}$. All the samples were analysed in a single assay with an intra-assay coefficient of variation $(\mathrm{CV})$, calculated from 20 random samples, of $6.3 \%$.

Somatotrophin. Concentrations of somatotrophin were determined as described by Lovendahl et al. (1991) and Gong et al. (1991), with a modification of the separation procedure. For the separation of bound and free tracer, a combination of sheep anti-guinea-pig $\operatorname{IgG}(1: 40)$ and normal guinea-pig serum (1:200) (SAPU, Carluke), instead of the cellulose-coupled donkey anti-guinea-pig serum, was used as the second antibody. Displacement curves of bST preparation used for injection and serum from both bST-treated and control heifers were parallel to the standard curve (data not shown). The crossreactions of FSH, $\mathrm{LH}$, prolactin and TSH in the assay were all $<0.01 \%$. The sensitivity of the assay was $0.65 \mathrm{ng} \mathrm{ml}^{-1}$. The interassay $\mathrm{CV}$ was $10.3 \%$ and the intra-assay $\mathrm{CV}$ was $7.1 \%$.

IGF-I. Peripheral IGF-I concentrations were measured using a radioimmunoassay described by Armstrong et al. (1990) and Gong et al. (1991). The minimum detectable concentration was $18.3 \mathrm{ng} \mathrm{ml}^{-1}$ and the interassay and intra-assay CVs were $9.6 \%$ and $6.4 \%$, respectively.

Insulin. Concentrations of insulin were assayed by a radioimmunoassay described previously by Osmond et al. (1981) and Gong et al. (1993a). The sensitivity of the assay was $0.07 \mathrm{ng} \mathrm{ml}^{-1}$. The interassay $\mathrm{CV}$ was $8.7 \%$ and the intra-assay CV was $7.2 \%$.

LH. Peripheral concentrations of $\mathrm{LH}$ were determined by a double-antibody radioimmunoassay routinely used in our laboratory (Price et al., 1987). The sensitivity of the assay was $0.13 \mathrm{ng} \mathrm{ml}^{-1}$. The inter- and intra-assay $\mathrm{CVs}$ were $10.1 \%$ and $5.9 \%$, respectively.

FSH. Peripheral FSH concentrations were measured using a radioimmunoassay developed in our laboratory (Gong et al., 1995). The detection limit of the assay was $0.09 \mathrm{ng} \mathrm{ml}^{-1}$. The interassay and intra-assay $\mathrm{CVs}$ were $9.8 \%$ and $6.3 \%$, respectively.

\section{Statistical analyses}

All the data are presented as means \pm SEM unless otherwise specified. The pulsatile profiles of LH measured in the serial plasma samples collected at 15 min intervals were determined using the Munro programme, as described by Veldhuis et al. (1986) and Gong et al. (1991). The effects of bST treatment on peripheral hormone concentrations and the number of follicles were analysed by ANOVA for repeated measurements. The main effects tested included treatment, time and interaction of 


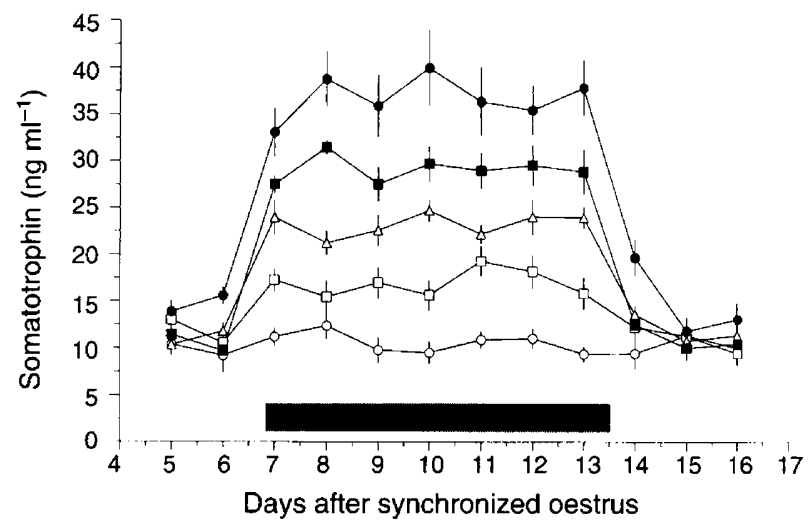

Fig. 1. Mean $\pm \operatorname{SEM}(n=4)$ serum somatotrophin concentrations for control heifers $(O)$ and four groups of heifers treated with recombinant bovine somatotrophin (bST) $\left(3.13 \mathrm{mg} \mathrm{day}^{-1}(\mathrm{c}), 6.25 \mathrm{mg} \mathrm{day}^{-1}(\Delta)\right.$, $12.5 \mathrm{mg} \mathrm{day}^{-1}(\mathbf{\bullet}), 25.0 \mathrm{mg}$ day ${ }^{-1}(\bullet)$, throughout the experimental period. Vehicle or bST were given four times a day at 06:00, 12:00, 18:00 and 24:00 $\mathrm{h}$ for 7 days, as indicated by the shaded bar. Samples were taken daily at 12:00 h.

treatment by time. When a significant effect of treatment was detected, a comparison was then made of different bST treatment groups with the control group, and a dose-dependent effect of bST was examined by regression analysis. Statistical differences in mean FSH concentrations, mean and basal $\mathrm{LH}$ concentrations, $\mathrm{LH}$ pulse frequency and $\mathrm{LH}$ pulse amplitude, measured from the serial blood samples, were tested by ANOVA. Data obtained from ultrasonography were recorded on videotapes and analysed as described by Gong et al. (1993a). Correlations between the number of ovarian follicles and peripheral somatotrophin, IGF-I and insulin concentrations were determined by regression analysis. All statistical analyses were performed using Minitab software (Pennsylvania State University).

\section{Results}

\section{Peripheral concentrations of somatotrophin}

Treatment with bST increased peripheral somatotrophin concentrations in a dose-dependent manner $(P<0.01)$ (Fig. I). Specifically, serum somatotrophin concentrations were significantly increased (effect of treatment, $P<0.01$; treatment by time, $P<0.05)$ in all four bST-treated groups when compared with the control group. The daily samples were taken just before the bST injection at $12.00 \mathrm{~h}$; therefore, increased somatotrophin profiles during the bST treatment (shown in Fig. 1) reflect the concentrations $6 \mathrm{~h}$ after injection. The increase in somatotrophin concentrations could still be detected $12 \mathrm{~h}$ after the termination of bST treatment in the group given $25.0 \mathrm{mg}$ but not in the other three treatment groups.

When serial samples obtained on days 1 and 5 of bST treatment were analysed, somatotrophin concentrations increased in a dose-dependent manner (effect of treatment, $P<0.01$ ), but the response profiles were not different (effect of time, $P<0.05$; treatment by time, $P>0.05$ ) among the four bST-treated groups (data not shown). Somatotrophin concen- trations increased within 30 min of bST injection, reached a maximum within $2 \mathrm{~h}$ and were still elevated $6 \mathrm{~h}$ later when the next bST injection was given.

\section{Peripheral IGF-I and insulin concentrations}

Overall, there was a significant effect $(P<0.05)$ of bST treatment on peripheral concentrations of both IGF-I and insulin. Serum concentrations of both IGF-I and insulin in heifers given 12.5 and $25.0 \mathrm{mg}$ bST day ${ }^{-1}$ were significantly higher (effect of treatment, $P<0.01$; treatment by time, $P<0.05$ ) than those in the controls (Table 1 ). In contrast, there was no effect of treatment with $3.13 \mathrm{mg} \mathrm{bST} \mathrm{day}{ }^{-1}$ on circulating concentrations of IGF-I and insulin. In the group given $6.25 \mathrm{mg}$, serum IGF-I and insulin concentrations were significantly increased (effect of treatment, $P<0.05$; treatment by time, $P<0.05)$. However, when analysed on an individual animal basis, only two heifers in this group showed a significant $(P<0.01)$ increase, while IGF-I and insulin concentrations in the other two heifers were not significantly different from those in the controls. For all the animals with an increase in serum IGF-I and insulin concentrations, no significant dosedependent effect of bST with doses of $6.25,12.5$ or $25.0 \mathrm{mg}$ was observed. Furthermore, the increase in serum IGF-I and insulin concentrations was observed within $30 \mathrm{~h}$ of the start of bST treatment and lasted until $36 \mathrm{~h}$ after the termination of treatment (data not shown).

In contrast to the acute response of somatotrophin concentrations to bST injections, no acute response in circulating IGF-I and insulin concentrations to bST injections was observed on either day 1 or day 5 of treatment. No effects of the first bST injection on IGF-I and insulin concentrations were observed. Both IGF-I and insulin were maintained at the mean concentrations shown in Table 2, with little fluctuation, throughout the $8 \mathrm{~h}$ sampling period.

\section{Peripheral concentrations of FSH, $L H$ and progesterone}

Serum concentrations of FSH in all the animals displayed a wave pattern, while $\mathrm{LH}$ was maintained at a basal concentration throughout the treatment (Fig. 2). However, no effect of bST treatment $(P>0.05)$ on either FSH or LH was observed. Therefore, the data from all four bST-treated groups were pooled for presentation.

On both day $I$ and day 5 of treatment (day 7 and day 11 of the oestrous cycle, respectively), peripheral concentrations of both FSH and $\mathrm{LH}$ did not show an acute response (effect of treatment, $P>0.05$; treatment by time, $P>0.05$ ) to bST injections. Mean FSH concentrations, mean and basal LH concentrations, LH pulse frequency and $\mathrm{LH}$ pulse amplitude were not altered by bST treatment (effect of treatment, $P>0.05$ ) (Table 3). Therefore, the data from the four bST-treated groups were pooled as a single group.

There was no effect of bST treatment on serum progesterone concentrations throughout the experimental period $(2.05 \pm$ $0.12 \mathrm{ng} \mathrm{ml}^{-1}$ for the control group and $2.02 \pm 0.06 \mathrm{ng} \mathrm{ml}^{-1}$ for the four bST-treated groups pooled).

When data on FSH, LH and progesterone were pooled for animals $(n=10)$ with increased IGF-I and insulin concentrations 
Table 1. Serum concentrations ( $\mathrm{ng} \mathrm{ml}^{-1}$ ) of insulin-like growth factor I (IGF-I) and insulin from days 5 to 16 of the oestrous cycle in heifers treated with different doses of recombinant bovine somatotrophin (bST) (overall mean \pm SEM for each group)

\begin{tabular}{lccccc}
\hline & \multicolumn{5}{c}{ bST $(\mathrm{mg})$} \\
\cline { 2 - 6 } & 0 & 3.13 & 6.25 & 12.5 & 25.0 \\
\hline IGF-I & $148.8 \pm 6.8$ & $147.9 \pm 6.3$ & $178.3 \pm 11.2^{*}$ & $212.4 \pm 9.3^{* *}$ & $227.9 \pm 10.5^{* *}$ \\
Insulin & $0.65 \pm 0.04$ & $0.67 \pm 0.04$ & $0.83 \pm 0.07^{*}$ & $0.93 \pm 0.05^{* *}$ & $0.98 \pm 0.06^{* *}$ \\
\hline
\end{tabular}

*Value is significantly different $(P<0.05)$ from control (concentrations in two heifers were not different from control.)

$* *$ Value is significantly different $(P<0.01)$ from control.

Table 2. Peripheral concentrations $\left(\mathrm{ng} \mathrm{ml}^{-1}\right.$ ) of insulin-like growth factor I (IGF-I) and insulin in heifers on day 1 and day 5 of treatment with recombinant bovine somatotrophin (bST) (overall mean \pm SEM for each group throughout the $8 \mathrm{~h}$ sampling period)

\begin{tabular}{|c|c|c|c|c|c|}
\hline & \multicolumn{5}{|c|}{ bST (mg) } \\
\hline & 0 & 3.13 & 6.25 & 12.5 & 25.0 \\
\hline \multicolumn{6}{|l|}{ Day 1} \\
\hline IGF-I & $144.6 \pm 3.8$ & $148.3 \pm 4.3$ & $137.9 \pm 4.6$ & $152.4 \pm 6.2$ & $142.9 \pm 5.5$ \\
\hline Insulin & $0.64 \pm 0.06$ & $0.65 \pm 0.04$ & $0.64 \pm 0.07$ & $0.67 \pm 0.05$ & $0.63 \pm 0.06$ \\
\hline \multicolumn{6}{|l|}{ Day 5} \\
\hline IGF-I & $138.8 \pm 4.1$ & $146.3 \pm 6.1$ & $203.4^{\mathrm{a}} \pm 13.1^{* *}$ & $247.4 \pm 10.3^{* *}$ & $258.6 \pm 15.5^{* *}$ \\
\hline Insulin & $0.65 \pm 0.06$ & $0.65 \pm 0.08$ & $0.93^{a} \pm 0.09 * *$ & $1.09 \pm 0.07^{* *}$ & $1.16 \pm 0.09^{* *}$ \\
\hline
\end{tabular}

**Value is significantly different $(P<0.01)$ from control.

${ }^{a}$ Concentrations in two heifers were not different from control.

and compared with those of the other ten heifers, no significant $(P>0.05)$ differences were observed.

\section{Ovarian follicular dynamics}

Overall, there was a significant effect $(P<0.05)$ of bST treatment on the numbers of ovarian antral follicles $<5 \mathrm{~mm}$ in diameter, as detected by ultrasonography. When analysed on an individual animal basis, this increase in numbers of small follicles was observed only in heifers with significantly increased circulating concentrations of IGF-I and insulin (all heifers from the groups given 12.5 or $25.0 \mathrm{mg}$ and two from the group given $6.25 \mathrm{mg}$ ). There was no difference in small follicle populations between the controls and all animals from the group given $3.13 \mathrm{mg}$ and the two remaining heifers from the group given $6.25 \mathrm{mg}$. The number of small follicles was positively correlated with both IGF-I $(r=0.69, P<0.01)$ and insulin $(r=0.72, P<0.01)$ concentrations, but not with somatotrophin concentrations $(r=0.23, P>0.05)$. Furthermore, for all the heifers with an increase in the numbers of small follicles, no significant dose-dependent effect of bST $(P>0.05)$ at doses of $6.25,12.5$ and $25.0 \mathrm{mg}$ was observed. Therefore, the data from these ten heifers were pooled as one group, while data from the other ten animals were pooled as a separate group (Fig. 3).

Treatment with bST did not affect the population of follicles $>5 \mathrm{~mm}$ in diameter, growth rate and diameter of the dominant follicle, or the turnover of follicular waves (data not shown). There was a dominant follicle present in all the heifers at the start of the experiment (day 5 of the oestrous cycle). A new follicular wave started on day $8.2 \pm 0.2(n=20)$ of the oestrous cycle, in close association with an increase in circulating $\mathrm{FSH}$ concentrations (Fig. 2), and a dominant follicle could be clearly detected approximately 3 days later. This dominant follicle was still present in all heifers at the end of the experiment (day 16 of the oestrous cycle), when a new follicular wave had been initiated in 14 of 20 heifers.

\section{Discussion}

This study has confirmed previous observations that treatment with bST can enhance the recruitment of ovarian follicles in cattle. Significantly, bST treatment was given in a more physiological regimen (four times per day and at lower doses) compared with previous studies. Moreover, this study demonstrated in vivo that the effect of bST treatment is probably mediated through an increase in circulating concentrations of IGF-I or insulin or both, rather than via a change in the secretion of pituitary gonadotrophins or a direct effect of bST on ovarian follicles.

Our previous studies in vitro (Gong et al., 1993b, 1994), investigating the mechanism underlying the effect of bST on ovarian follicles, have suggested that bST may not act directly 
(a)
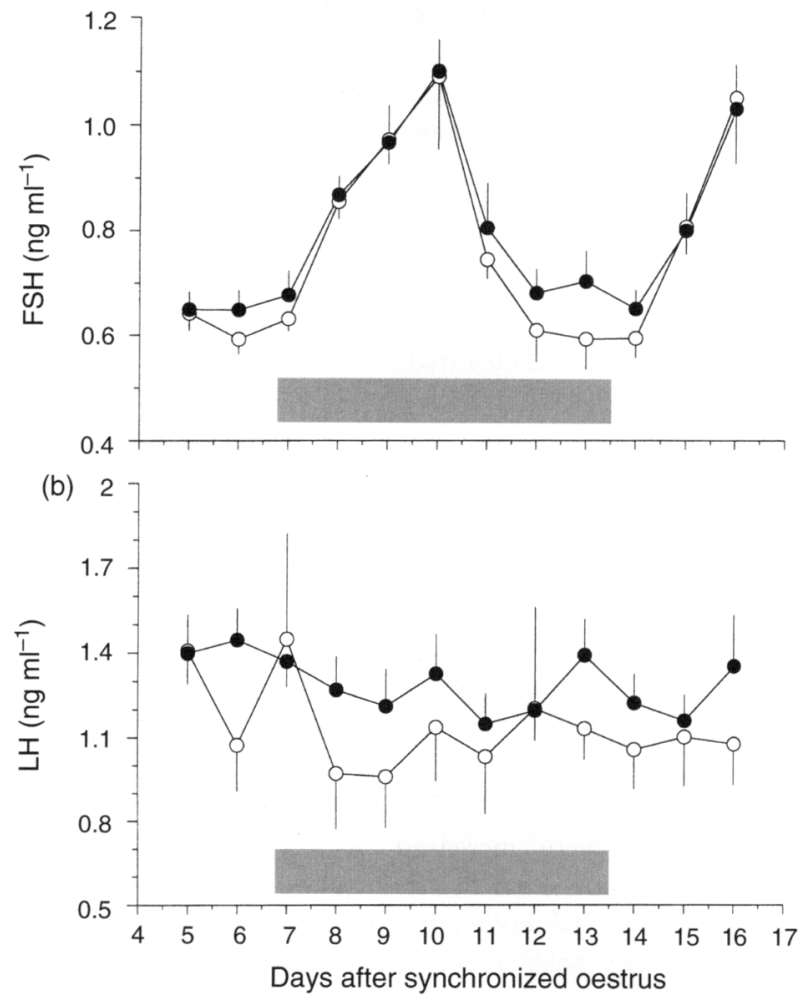

Fig. 2. Daily serum concentrations (mean \pm SEM) of (a) FSH and (b) LH in control heifers $(0, n=4)$ and groups of heifers treated with recombinant bovine somatotrophin (bST) $(\bullet, n=16)$ throughout the experimental period. The data from the four bST-treated groups were pooled as there was no effect of treatment. Vehicle or bST injections were given four times a day for 7 days, as indicated by the shaded bar, with samples taken daily at $12: 00 \mathrm{~h}$.

on follicles and that the effect of bST is most likely to be mediated through increased concentrations of IGF-I or insulin, or both, acting in synergy with gonadotrophins. This contention was supported by the failure to demonstrate somatotrophin binding to bovine granulosa cells (J. G. Gong, R. Webb and T. A. Bramley, unpublished), and by the results of Lucy ef al. (1993b) who found no expression of mRNA or protein for a bovine somatotrophin receptor in bovine follicles. Our current study has provided direct evidence in vivo to support these previous observations (Gong et al., 1993b; Lucy et al., 1993b; Gong et al., 1994). We found that the increase in the number of small follicles was observed only in animals with significantly increased IGF-I and insulin concentrations, but not in heifers with increased somatotrophin concentrations alone. Furthermore, the number of small follicles was positively correlated with both IGF-I and insulin concentrations, but not with somatotrophin concentrations. Additional support comes from a recent study (Gutierrez et al., 1997), which demonstrated that increased dietary intake in heifers acutely enhanced the recruitment of small follicles, in association with significantly higher serum insulin concentrations (the increase is comparable with that following bST treatment) but lower circulating somatotrophin concentrations. However, the relative importance of IGF-I and insulin remains unclear. While it has been well-accepted that IGF-I is involved in the control of ovarian follicle development (see Spicer and Echternkamp, 1995), the importance of insulin was demonstrated in vivo by Gutierrez et al. (1997) who found that the increase in the number of small follicles was associated with an increase in peripheral concentrations of insulin, while circulating IGF-I concentrations appeared to remain unchanged.

In agreement with previous studies (Gallo and Block, 1991; Gong et al., 1991, 1993a; Herrler et al., 1994; Pavlok et al., 1996), and as expected, bST treatment significantly increased peripheral concentrations of somatotrophin, IGF-I and insulin. However, previous studies with lactating dairy cows found that bST treatment usually does not induce an increase in peripheral insulin concentrations (see Vernon, 1990; Gallo and Block, 1991; De La Sota et al., 1993). As reported previously (Gong et al., 1991, 1993a; Herrler et al., 1994), the increase in circulating IGF-I and insulin concentrations was observed within $30 \mathrm{~h}$ of the increase in somatotrophin concentrations. However, unlike somatotrophin, IGF-I and insulin did not respond acutely to each bST injection, but remained at a constant high concentration after the initial increase (Gong et al., 1991, 1993a). Presumably, peripheral somatotrophin concentrations increased as a direct result of exogenous bST injections; therefore, the increase was bST-dose-dependent and was observed in all the bST-treated groups. In contrast, IGF-I and insulin increased in response to bST treatment, but only in animals receiving the higher doses $\left(\geq 6.25 \mathrm{mg} \mathrm{day}^{-1}\right)$ of bST, suggesting that a possible threshold is required for an increase in IGF-I and insulin.

This study has also confirmed and extended previous data (Gong et al., 1991) showing that bST treatment does not affect the secretion of LH and FSH: neither alterations in peripheral $\mathrm{LH}$ and $\mathrm{FSH}$ concentrations throughout the treatment period nor acute responses of FSH and LH secretion to bST on day I and day 5 of treatment were observed. In contrast, Schemm et al. (1990) found that LH pulse frequency tended to be higher, while basai and mean LH concentrations were significantly lower in the first follicular phase following bST treatment during the postpartum period in lactating dairy cows. However, these effects of bST were no longer observed by the third follicular phase following the treatment. Gallo and Block (1991) also reported that bST treatment given between days 3 and 15 postpartum in lactating dairy cows enhanced the pituitary $\mathrm{LH}$ response to a $\mathrm{GnRH}$ chailenge. However, it is still not clear how bST treatment acts to alter the secretion of LH, although it has been speculated that blood-borne metabolites such as insulin and glucose might be involved in the control of $\mathrm{GnRH}$ secretion (Adam et al., 1996; see Robinson, 1996).

In this and our previous studies (Gong et al., 1991, 1993a), no effect of bST treatment on peripheral progesterone concentrations has been observed. However, in studies by Schemm et al. (1990) and Gallo and Block (1991), plasma concentrations of progesterone were increased during the first and second oestrous cycles, but not during the third or subsequent cycles, after bST treatment of postpartum, lactating dairy cows. The mechanism(s) underlying this effect of bST remains unclear, although an increase in circulating IGF-I and insulin concentrations induced by bST treatment may be involved. It has been shown that binding sites for IGF-I and insulin are present in bovine luteal tissue and that IGF-I and insulin can stimulate 
Table 3. Plasma FSH and $\mathrm{LH}$ concentrations ( $\mathrm{ng} \mathrm{ml}^{-1}$ ) and $\mathrm{LH}$ pulsatile profiles throughout the $8 \mathrm{~h}$ sampling period on day 1 and day 5 of treatment with recombinant bovine somatotrophin (bST) in heifers

\begin{tabular}{lccccc}
\hline & Mean FSH & Mean LH & Basal LH & $\begin{array}{c}\text { LH puise } \\
\text { frequency (8 h) }\end{array}$ & $\begin{array}{c}\text { LH pulse } \\
\text { amplitude }\end{array}$ \\
\hline Day 1 & & & & & \\
$\quad$ Control $(n=4)$ & $0.62 \pm 0.04$ & $1.35 \pm 0.12$ & $1.27 \pm 0.07$ & $2.75 \pm 0.25$ & $0.48 \pm 0.07$ \\
$\quad$ bST-treated $(n=16)$ & $0.65 \pm 0.05$ & $1.29 \pm 0.09$ & $1.21 \pm 0.06$ & $2.43 \pm 0.16$ & $0.54 \pm 0.06$ \\
Day 5 & & & & & \\
$\quad$ Control $(n=4)$ & $0.73 \pm 0.07$ & $1.09 \pm 0.08$ & $1.03 \pm 0.07$ & $2.00 \pm 0.41$ & $0.42 \pm 0.07$ \\
bST-treated $(n=16)$ & $0.75 \pm 0.08$ & $1.12 \pm 0.11$ & $1.05 \pm 0.05$ & $2.06 \pm 0.17$ & $0.45 \pm 0.04$ \\
\hline
\end{tabular}

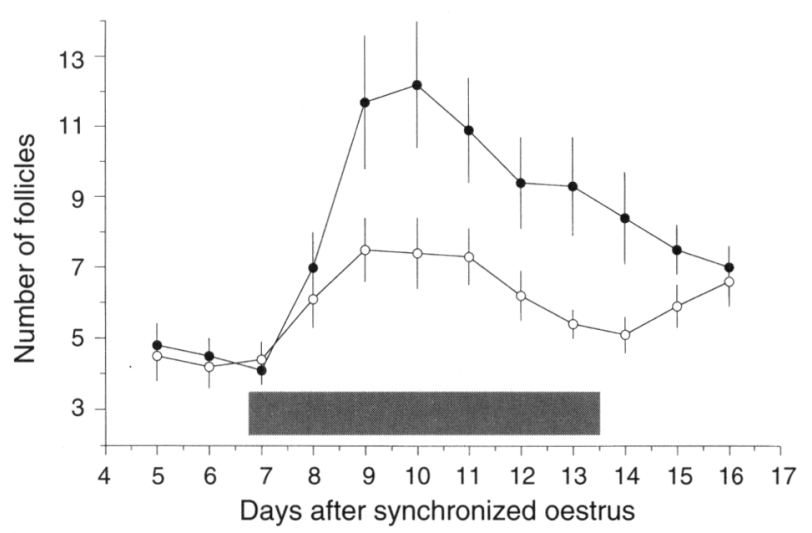

Fig. 3. Mean \pm SEM number of follicles $<5 \mathrm{~mm}$ in diameter, detected by real time ultrasonography, throughout the experimental period for heifers without $(, n=10)$ or with $(\bullet, n=10)$ significantly increased serum concentrations of insulin-like growth factor I (IGF-I) and insulin following treatment with recombinant bovine somatotrophin (bST). Vehicle or bST injections were given four times a day for 7 days, as indicated by the shaded bar, with ultrasound scanning carried out daily.

progesterone secretion by bovine luteal cells (Sauerwein $e$ al., 1992). Furthermore, bST might act directly on corpora lutea, as both mRNA and protein for a bovine somatotrophin receptor has been demonstrated to be present in bovine corpora lutea (Tanner and Hauser, 1989; Lucy et al., 1993b).

In agreement with previous studies (Gong et al., 1991, 1993a; De La Sota et al., 1993; Lucy et al., 1993a; Herrler et al., 1994), bST treatment significantly increased the population of small antral follicles. There were no effects of treatment on the number of medium-sized or large follicles. Furthermore, the dynamics of follicular waves and dominant follicle development in association with changes in circulating FSH concentrations were similar to those reported previously (Adams $e$ al., 1992; Gong et al., 1995), and were unaffected by bST treatment. These results suggest that metabolic hormones such as somatotrophin, IGF-I and insulin are involved in the gonadotrophin-independent stages of follicle development ( $\leq 4 \mathrm{~mm}$ in diameter; Gong et al., 1996) in cattle, and may be one of the mechanisms mediating the well-recognized, but poorly understood, influence of nutrition on reproduction (see Gong and Webb, 1996; see Robinson, 1996).

Our results (Gong et al., 1991, 1993a and current study) and those of others (Schemm et al., 1990; Gallo and Block, 1991;
De La Sota et al., 1993) have indicated a possible difference between beef heifers and lactating dairy cows in the response of $\mathrm{LH}$ secretion and of peripheral insulin and progesterone concentrations to bST treatment (see discussion above). The reason for this apparent difference is unknown, although it may be due to the differences in nutritional status (energy balance) and body condition associated with lactation (see Robinson, 1996). In the study of De La Sota et al. (1993), peripheral insulin concentrations were increased by bST treatment in nonlactating dairy cows, but not in lactating ones. Furthermore, in our experiments, heifers were in good body condition and no negative energy balance was observed during bST treatment. In the studies by Schemm et al. (1990) and Gallo and Block (1991), the effect of bST on LH and progesterone was observed in the early stage of treatment (early postpartum period) when animals had a poor body condition and were under negative energy balance, but not when animals had attained a zero or positive energy balance (Schemm et al., 1990; Gallo and Block, 1991).

In summary, this study has shown that the stimulatory effect of bST treatment on ovarian follicle development in heifers is probably mediated by increased concentrations of IGF-I and insulin, rather than by an alteration in the secretion of pituitary gonadotrophins or a direct effect of bST on ovarian follicles. However, the relative importance of IGF-I and insulin remains to be determined.

This work was supported by BBSRC, MAFF and OST. The authors would like to thank Elanco Animal Health for the gift of bST; NIDDK, NHPP, USDA Animal Hormone Program and SAPU for the reagents for radioimmunoassays; and I. Swanston (MRC Reproductive Biology Unit) for $\left[{ }^{125} \mathrm{I}\right]$ progesterone. They also wish to thank the staff at the Institute's Large Animal Unit and Dryden farm for the care and general handling of experimental animals.

\section{References}

Adam CL, Findlay PA and Hotston Moore A (1996) Acute effects of insulin on LH secretion in sheep Journal of Reproduction and Fertility Abstract Series 17 Abstract 123

Adams GP, Matteri RL, Kastelic JP, Ko JCH and Ginther OJ (1992) Association between surges of follicle-stimulating hormone and the emergence of follicular waves in heifers Journal of Reproduction and Fertility 94 177-188

Armstrong DG, Duclos MJ and Goddard C (1990) Biological activity of insulin-like growth factor-I purified from chicken serum Domestic Animal Endocrinology 7 383-393 
Corrie JET, Hunter WM and Macpherson IS (1981) A strategy for radioimmunoassay of plasma progesterone with the use of a homologous site ${ }^{125}$ I-labelled radioligand Clinical Chemistry 27 594-599

De La Sota RL, Lucy MC, Staples CR and Thatcher WW (1993) Effect of recombinant bovine somatotropin (sometribove) on ovarian function in lactating and nonlactating dairy cows Journal of Dairy Science 76 1002-1013

Gallo GF and Block E (1991) Effects of recombinant bovine somatotropin on hypophyseal and ovarian functions of lactating dairy cows Canadian Journal of Animal Science 71 343-353

Gong JG and Webb R (1996) Control of ovarian follicle development in domestic ruminants: its manipulation to increase ovulation rate and improve reproductive performance Animal Breeding Abstracts 64 195-204

Gong JG, Bramley TA and Webb R (1991) The effect of recombinant bovine somatotrophin on ovarian function in heifers: follicular populations and peripheral hormones Biology of Reproduction 45 941-949

Gong JG, Bramley TA and Webb R (1993a) The effect of recombinant bovine somatotrophin on ovarian follicular growth and development in heifers Journal of Reproduction and Fertility 97 247-254

Gong JG, McBride D, Bramley TA and Webb R (1993b) Effects of recombinant bovine somatotrophin, insulin-like growth factor-I and insulin on the proliferation of bovine granulosa cells in vitro. Journal of Endocrinology 139 $67-75$

Gong JG, McBride D, Bramley TA and Webb R (1994) Effects of recombinant bovine somatotrophin, insulin-like growth factor-I and insulin on bovine granulosa cell steroidogenesis in vitro. Journal of Endocrinology 143 157-164

Gong JG, Bramley TA, Gutierrez CG, Peters AR and Webb R (1995) Effects of chronic treatment with a gonadotrophin-releasing hormone agonist on peripheral concentrations of FSH and $\mathrm{LH}$, and ovarian function in heifers Journal of Reproduction and Fertility 105 263-270

Gong JG, Campbell BK, Bramley TA, Gutierrez CG, Peters AR and Webb R (1996) Suppression in the secretion of follicle-stimulating hormone and luteinizing hormone, and ovarian follicle development in heifers continuously infused with a gonadotrophin-releasing hormone agonist Biology of Reproduction 55 68-74

Gutierrez CG, Campbell BK and Webb R (1995) IGF-I stimulation of oestradiol production and proliferation of bovine granulosa cells: interaction with FSH and insulin Journal of Reproduction and Fertility Abstract Series 15 Abstract 139

Gutierrez CG, Oldham J, Bramley TA, Gong JG, Campbell BK and Webb R The recruitment of ovarian follicles is enhanced by increased dietary intake in heifers Journal of Animal Science (in press)

Herrler A, Einspanier R, Schams D and Niemann H (1994) Effect of recombinant bovine somatotropin (rBST) on follicular IGF-I contents and the ovarian response following superovulatory treatment in dairy cows: a preliminary study Theriogenology $41601-611$

Langhout DJ, Spicer LJ and Geisert RD (1991) Development of a culture system for bovine granulosa cells: effects of growth hormone, estradiol, and gonadotropins on cell proliferation, steroidogenesis, and protein synthesis Journal of Animal Science 69 3321-3334

Law AS, Baxter G, Logue DN, O'Shea T and Webb R (1992) Evidence for the action of bovine follicular fluid factor(s) other than inhibin in suppressing follicular development and delaying oestrus in heifers Journal of Reproduction and Fertility 96 603-616

Lovendahl P, Angus KB and Woolliams JA (1991) The effect of selection for milk yield on the response to growth hormone secretagogues in immature cattle Journal of Endocrinology 128 419-424
Lucy MC, De La Sota RL, Staples CR and Thatcher WW (1993a) Ovarian follicular populations in lactating dairy cows treated with recombinant bovine somatotropin (sometribove) or saline and fed diets differing in fat content and energy Joumal of Dairy Science 76 1014-1027

Lucy MC, Collier RJ, Kitchell ML, Dibner JJ, Hauser SD and Krivi GG (1993b) Immunohistochemical and nucleic acid analysis of somatotropin receptor populations in the bovine ovary Biology of Reproduction 48 1219-1227

Osmond TJ, Carr WR, Hinks CJM, Land RB and Hill WG (1981) Physiological attributes as possible selection criteria for milk production: 2. plasma insulin, triiodothyronine and thyroxine in bull Animal Production 32 159-163

Pavlok A, Koutecka L, Krejci P, Slavik T, Cerman J, Slaba J and Dorn D (1996) Effect of recombinant bovine somatotropin on follicular growth and quality of oocytes in cattle Animal Reproduction Science 41 183-192

Price CA, Morris BA and Webb R (1987) Reproductive and endocrine effects of active immunization against a testosterone conjugate in heifers Journal of Reproduction and Fertility 81 149-160

Robinson JJ (1996) Nutrition and reproduction Animal Reproduction Science $\mathbf{4 2}$ 25-34

Sauerwein H, Miyamoto J, Gunther J, Meyer HHD and Schams D (1992) Binding and action of insulin-like growth factors and insulin in bovine luteal tissue during the oestrous cycle Journal of Reproduction and Fertility 96 103-115

Saumande J (1991) Culture of bovine granulosa cells in a chemically defined serum-free medium: the effect of insulin and fibronectin on the response to FSH Journal of Steroid Biochemistry and Molecular Biology 38 189-196

Savion N, Liu GM, Laherty R and Gospodarowicz D (1981) Factors controlling proliferation and progesterone production by bovine granulosa cells in serum-free medium Endocrinology 109 409-420

Schemm SR, Deaver DR, Griel LC, Jr and Muller LD (1990) Effect of recombinant bovine somatotropin on luteinizing hormone and ovarian function in lactating dairy cows Biology of Reproduction 42 815-821

Sirotkin AV and Makarevic AV (1996) The role of growth hormone and of cAMP-dependent intracellular mechanisms in the control of IGF-I, oxytocin and oestradiol secretion by bovine granulosa cells Journal of Reproduction and Fertility Abstract Series 17 Abstract 128

Spicer LJ and Echternkamp SE (1995) The ovarian insulin and insulin-like growth factor system with an emphasis on domestic animals Domestic Animal Endocrinology 12 223-245

Spicer LJ, Alpizar E and Echternkamp SE (1993) Effects of insulin, insulin-like growth factor I, and gonadotropins on bovine granulosa cell proliferation, progesterone production, estradiol production, and (or) insulin-like growth factor I production in vitro. Journal of Animal Science 71 1232-1241

Tanner JW and Hauser SD (1989) Molecular evidence for the presence of the somatotropin receptor in the bovine ovary Journal of Animal Science 67 (Supplement 1) Abstract 413

Veldhuis JD, Weiss J, Mauras N, Rogol AD, Evans WS and Johnson ML (1986) Appraising endocrine pulse signals at low circulating hormone concentrations: use of regional coefficients of variation in the experimental series to analyse pulsatile luteinizing hormone release Pediatrics Research $\mathbf{2 0}$ 632-637

Vernon RG (1990) Influence of somatotropin on metabolism. In Use of Somatotropin in Livestock Production pp 31-50 Eds K Sejrsen, M Vestergaard and A Niemann-Sorensen. Elsevier Applied Science, London and New York

Webb R, Gong JG and Bramley TA (1994) Role of growth hormone and intrafollicular peptides in the control of follicle development in cattle Theriogenology 41 25-30 